\title{
Effects of light-curing time on the cytotoxicity of a restorative composite resin on odontoblast- like cells
}

\author{
Andreza Maria Fábio ARANHA 1 , Elisa Maria Aparecida GIRO², Josimeri HEBLING ${ }^{2}$, Fernanda Campos Rosetti \\ LESSA $^{3}$, Carlos Alberto de Souza COSTA ${ }^{4}$
}

1- DDS, MS, PhD, Postdoctoral fellow of Department of Biology Science, University of São Paulo, Bauru School of Dentistry, Bauru, SP, Brazil.

2- DDS, MS, PhD, Full Professor, Discipline of Pediatric Dentistry, Department of Orthodontics and Pediatric Dentistry, São Paulo State University, Araraquara Dental School, Araraquara, SP, Brazil.

3- DDS, MS, PhD, Professor, Discipline of Pathology, Vila Velha University Center, Vitória, ES, Brazil.

4- DDS, MS, PhD, Full Professor, Discipline of Pathology, Department of Physiology and Pathology, São Paulo State University, Araraquara Dental School, Araraquara, SP, Brazil.

Corresponding address: Prof. Dr. Carlos Alberto de Souza Costa - Departamento de Fisiologia e Patologia - Faculdade de Odontologia de Araraquara UNESP - Rua Humaitá, 1680 - Centro - 14801-903 - Araraquara, SP - Brasil - Phone: +55-16-3301-6477 - Fax: 55-16-3301-6488 - e-mail: casouzac@foar. unesp.br

Received: February 10, 2009 - Modification: September 5, 2009 - Accepted: October 22, 2009

\section{ABSTRACT}

This in vitro study evaluated the cytotoxicity of an experimental restorative composite resin subjected to different light-curing regimens. Methods: Forty round-shaped specimens were prepared and randomly assigned to four experimental groups $(n=10)$, as follows: in Group 1, no light-curing; in Groups 2, 3 and 4, the composite resin specimens were light-cured for 20, 40 or $60 \mathrm{~s}$, respectively. In Group 5, filter paper discs soaked in $5 \mu \mathrm{L}$ PBS were used as negative controls. The resin specimens and paper discs were placed in wells of 24-well plates in which the odontoblast-like cells MDPC-23 $\left(30,000 \mathrm{cells} / \mathrm{cm}^{2}\right)$ were plated and incubated in a humidified incubator with $5 \% \mathrm{CO}_{2}$ and $95 \%$ air at $37^{\circ} \mathrm{C}$ for $72 \mathrm{~h}$. The cytotoxicity was evaluated by the cell metabolism (MTT assay) and cell morphology (SEM). The data were analyzed statistically by Kruskal-Wallis and MannWhitney tests $(p<0.05)$. Results: In $G 1$, cell metabolism decreased by $86.2 \%$, indicating a severe cytotoxicity of the non-light-cured composite resin. On the other hand, cell metabolism decreased by only $13.3 \%$ and $13.5 \%$ in G2 and G3, respectively. No cytotoxic effects were observed in G4 and G5. In G1, only a few round-shaped cells with short processes on their cytoplasmic membrane were observed. In the other experimental groups as well as in control group, a number of spindle-shaped cells with long cytoplasmic processes were found. Conclusion: Regardless of the photoactivation time used in the present investigation, the experimental composite resin presented mild to no toxic effects to the odontoblast-like MDPC-23 cells. However, intense cytotoxic effects occurred when no light-curing was performed.

Keywords: Dental materials. Cytotoxicity. Dental pulp. Cultured cells.

\section{INTRODUCTION}

Due to the growing demand of patients for esthetic restorations and the concern about the possible adverse effects of the mercury released from amalgam, the search for direct composite resins has increased considerably and their use in posterior teeth is now also a routine in dental practice.

It has been demonstrated that the extent of polymerization of resin materials is directly related to the quality of their physical, mechanical and biological properties ${ }^{22,23}$. When a material is underpolymerized due to low light intensity delivered from the curing unit or inadequate light exposure time, free resin monomers that were not converted into a polymer network may remain in the deeper areas of composite resin restorations and may be released from the material, contributing to weaken the restoration and alter color stability ${ }^{7,24}$. Unreacted monomers located on the base of composite resin restorations can diffuse through the polymerized bonding agent and dentinal tubules to reach the pulp tissue ${ }^{9}$. These resin components 
are cytotoxic $6,14,17,21$ and may cause local tissue irritation and pulpal inflammation ${ }^{3,26,27}$, especially when applied in very deep cavities ${ }^{9}$.

Numerous factors may affect the polymerization of resin restorative materials, such as the light intensity emitted by the curing units and the light-curing time, as well as thickness of overlying restorative material, its composition and color ${ }^{4,22}$. The duration of light exposure is one of the most important variables governing the polymerization of light-activated restorative composites. It can be a rate-limiting step in the polymerization process when using light-source intensities greater than $280 \mathrm{~mW} / \mathrm{cm}^{2}$ and when the incremental layer thickness does not exceed $2 \mathrm{~mm}^{21}$.

Several methodologies have been proposed to evaluate the cytotoxicity of dental materials and their components. For a long time, in vitro cell culture experiments have been widely used $^{1,6,11,17,19,27}$. Although there is no consensus in the literature regarding the most indicated cell type for these kind of investigations, cells from the odontoblast-like MDPC-23 cell line (mouse dental papillae cells) have been frequently used ${ }^{1,6,27}$, mainly because of their odontoblast phenotype ${ }^{11}$. In addition, odontoblasts are the first cell line to receive components released from restorative dental materials that are capable of diffusing across dentinal tubules. The aim of this in vitro study was to evaluate the influence of the curing time on the cytotoxicity of a restorative composite resin on immortalized odontoblast-like MDPC-23 cells.

\section{MATERIAL AND METHODS}

\section{Cell Culture}

Odontoblast-like cells (MDPC-23 cells) ${ }^{11}$ were cultured at $30 \times 10^{4} / \mathrm{cm}^{2}$ in complete Dulbecco's Modified Eagle's Medium (DMEM; Sigma Chemical Co., St. Louis, MO, USA) supplemented with $10 \%$ fetal bovine serum (Gibco, Grand Island, NY, USA), with $100 \mathrm{IU} / \mathrm{mL}$ penicillin, $100 \mathrm{mg} / \mathrm{mL}$ streptomycin and $2 \mathrm{mM} / \mathrm{L}$ glutamine (Gibco). The cells were allowed to grow for $72 \mathrm{~h}$ in a humidified incubator at $37^{\circ} \mathrm{C}$ with $5 \% \mathrm{CO}_{2}$ and $95 \%$ air (Isotemp; Fisher Scientific, Pittsburgh, PA, USA).

\section{Preparation of Composite Resin Specimens}

Forty experimental round-shaped composite resin (organic matrix: Bis-GMA/TEGDMA; inorganic fillings: zirconia/silica- $66 \%$ of volume) specimens ( $4 \mathrm{~mm}$ in diameter $\times 2 \mathrm{~mm}$ thick) were prepared using a split stainless steel matrix with the same dimensions (Incombi; Indústria e Comércio de Máquinas Biagioni Ltda., Araraquara, SP, Brazil). The specimens were distributed into four experimental groups $(n=10)$ according to the curing time used for composite resin photoactivation: Group 1 (G1) - dark curing; Groups 2, 3 and 4 (G2, G3 and G4) - the composite resin specimens were light-cured for 20, 40 and $60 \mathrm{~s}$, respectively; in G5 (control group), 10 sterile 4-mm-diamater filter paper discs (Matheson Scientific Inc., E\&D 613, MI, USA) were soaked with $5 \mu \mathrm{L}$ phosphate buffered saline solution (PBS). After the insertion in the stainlesssteel molds, the material was covered by a plastic strip to avoid the oxygen inhibiting layer, and a standardized load $(500 \mathrm{~g})$ was applied to promote the overflow of material. The selected specimens were light-activated at one end with a halogen lightcuring unit (Optilux 500, Demetron/Kerr, Danbury, CT, USA). The light intensity was monitored with a radiometer (Optilux 500, Demetron/Kerr, Danbury, CT, USA, $\left.410 \mathrm{~mW} / \mathrm{cm}^{2}\right)^{21}$. In Group 1, the specimens were allowed to set in the dark for 15 min in an incubator at $37^{\circ} \mathrm{C}$ with $100 \%$ humidity.

After light- or dark-curing of the material, the specimens were removed from the molds and rinsed under agitation with PBS and DMEM culture medium during $5 \mathrm{~min}$ each. Then, the roundshaped resin specimens were placed individually on the bottom of the wells of sterile 24-well plates (Costar Corp., Cambridge, MA, USA). The specimens were maintained in place under slight pressure, by means of a hand-made orthodontic wire clasp in a shape of an inverted loop. MDPC-23 cells were seeded at an initial density of 30,000 cells $/ \mathrm{cm}^{2}$ in each well containing $1 \mathrm{~mL}$ of complete DMEM supplemented with $10 \%$ FBS (Gibco, Grand Island, NY, USA), $100 \mathrm{IU} / \mathrm{mL}$ penicillin, $100 \mathrm{mg} /$ $\mathrm{mL}$ streptomycin and $2 \mathrm{mM} / \mathrm{L}$ glutamine (Gibco). The well-plates were maintained for $72 \mathrm{~h}$ in a humidified incubator (Isotemp; Fisher Scientific) at $37^{\circ} \mathrm{C}$ with $5 \% \mathrm{CO}_{2}$ and $95 \%$ air.

\section{Analysis of Cell Metabolism}

Cell metabolic activity was evaluated by succinic dehydrogenase (SDH) activity, which is a measure of the mitochondrial respiration of the cells. For this purpose, the methyltetrazolium (MTT) assay was used ${ }^{18}$.

To assess the cell metabolism, the resin specimens were removed from 8 wells of each group and the culture medium was replaced by 900 $\mathrm{mL}$ of DMEM and $100 \mu \mathrm{L}$ of MTT solution (Sigma Chemical Co., USA) ( $5 \mathrm{mg} / \mathrm{mL}$ PBS). The cells were incubated at $37^{\circ} \mathrm{C}$ for 4 hours with $5 \% \mathrm{CO}_{2}$ and $95 \%$ air. Thereafter, the culture medium which had been mixed with the MTT solution was aspirated and replaced by $600 \mu \mathrm{L}$ of acid- isopropanol solution ( $100 \mu \mathrm{L}$ of $0.04 \mathrm{~N} \mathrm{HCl}$ in isopropanol) in each well to dissolve the dark blue crystals formed in the presence of active mitochondria. The optical density of the solutions was determined by means of a spectrophotometer (ELX 800 - Universal Microplate Reader; Bio-Tek instrument, Inc., Winooski, VT, USA), using a test wavelength of 570 $\mathrm{nm}$. Detailed procedures for these measurements were previously described by Mosmann ${ }^{18}$ (1983). 
Table 1- SDH enzyme activity of the odontoblast-like cells (MDPC-23) detected by the MTT assay as a function of the curing time

\begin{tabular}{lcccc}
\hline Material & \multicolumn{5}{c}{ Curing time } & 40 s & 60 s \\
\hline & $\mathbf{0 ~ s}$ (dark-curing) & s & & \\
\hline $\begin{array}{l}\text { Experimental } \\
\text { composite } \\
\text { resin } \\
\text { (G1-G4) }\end{array}$ & $0.055(0.053-0.063)$ a A & $0.390(0.308-0.408)$ a A & $0.402(0.283-0.421)$ ab A & $0.451(0.398-0.487)$ b A \\
$\begin{array}{l}\text { PBS } \\
\text { (G5) }\end{array}$ & $0.421(0.412-0.438)$ b B & $0.421(0.412-0.438)$ b B & $0.421(0.412-0.438)$ a B & $0.421(0.412-0.438)$ a B \\
\hline
\end{tabular}

Values represent median (percentile 25-percentile 75), optical density (OD). Medians followed by the same lowercase letters in the rows and uppercase letters in the columns are statistically not different (Mann-Whitney, $p>0.05$ )

\section{Analysis of Cell Morphology by Scanning Electron Microscopy (SEM)}

Cell morphology was assessed in two specimens of each group, using a scanning electron microscope (JEOL-JMS-T33A Scanning Microscope). For such purpose, sterile 12-mm-diameter cover glasses (Fisher Scientific) were placed on the bottom of two wells before placement of the resin specimens and seeding of the MDPC-23 cells $(30,000$ cells/ $\mathrm{cm}^{2}$ ). After 72-h incubation, the resin specimens were removed from the wells and the cells were fixed in $2.5 \%$ glutaraldehyde solutions for $24 \mathrm{~h}$, post-fixed for $60 \mathrm{~min}$ in $1 \%$ osmium tetroxide, dehydrated in a series of increasing ethanol concentrations, and were subjected to drying with the hexamethyldisilazane solvent (HMDS; Acros Organics, Springfield, NJ, USA). Finally, the cells were mounted on metallic stubs, sputter-coated with gold and had their morphology examined with a scanning electron microscope (JEOL-JMS-T33A, Tokyo, Japan).

\section{Statistical Analysis}

Both experiments (cell metabolism assay and morphological analysis) were performed in triplicate to ensure the reproducibility.

As cell metabolism activity data had a nonnormal distribution, the non-parametric KruskalWallis test was used for analysis of the variables material and light-curing time, complemented by Mann-Whitney tests. Significance level was set at $\alpha=0.05$ for all analyses. The analysis of cell morphology was performed descriptively.

\section{RESULTS}

\section{Cell Metabolism (MTT assay)}

The results of cell metabolism after $72 \mathrm{~h}$ of direct contact of the composite resin with the MDPC-23 cells are presented in Table 1.

There was statistically significant difference $(p<0.05)$ between the test material (experimental composite resin) and the negative control (PBS), as well as between the different light-curing times $(p<0.05)$. Regardless of the light-curing time, the composite resin presented mild or no toxic effect to the MDPC-23 cells. However, when dark-curing was done, the direct contact with the material caused a reduction of $86.2 \%$ in cell metabolism, while the reduction seen for the other three curing times was $13.3 \%$ for $20 \mathrm{~s}, 13.5 \%$ for $40 \mathrm{~s}$ and $0 \%$ for $60 \mathrm{~s}$.

G4 and G5 presented statistically similar values of MDPC-23 cell metabolic activity ( 0.451 and 0.421 , respectively) $(p>0.05)$, while the values for G2 (0.390) and G3 (0.402) differed significantly $(p<0.05)$ from those of G1 (0.055) and G4 (0.451).

\section{Cell Morphology (SEM)}

In the negative control group (G5), the MDPC23 cells that remained attached to the glass substrate were organized in epithelioid nodules. Morphologically, the MDPC-23 cells were spindleshaped and presented numerous cytoplasmic processes, which seemed to be keeping the cells attached to the glass substrate (Figure 1). Cells from the groups in which the composite resin was light-activated for $40 \mathrm{~s}$ (G3) and $60 \mathrm{~s}$ (G4) exhibited similar morphological characteristics (Figures 2A and $2 \mathrm{~B}$ ). On the other hand, in G2 (20 s-lightactivation), a small number of MDPC-23 cells

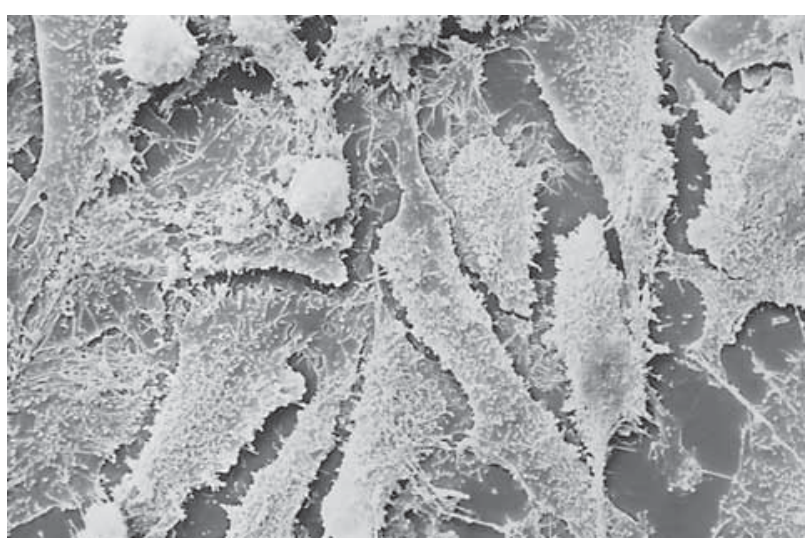

Figure 1- Negative control group (PBS-G5) - Presence of spindle-shaped cells organized in dense nodules and long cytoplasmic processes (Original magnification: $\mathrm{x} 1,000$ ) 


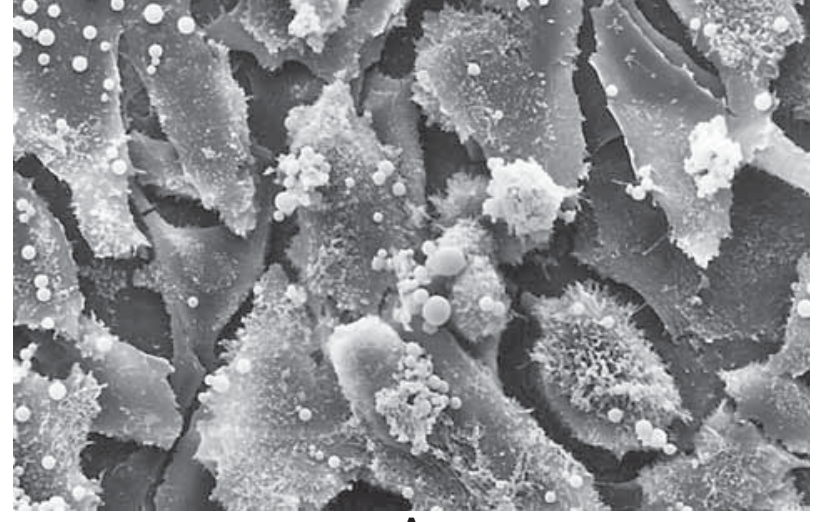

A

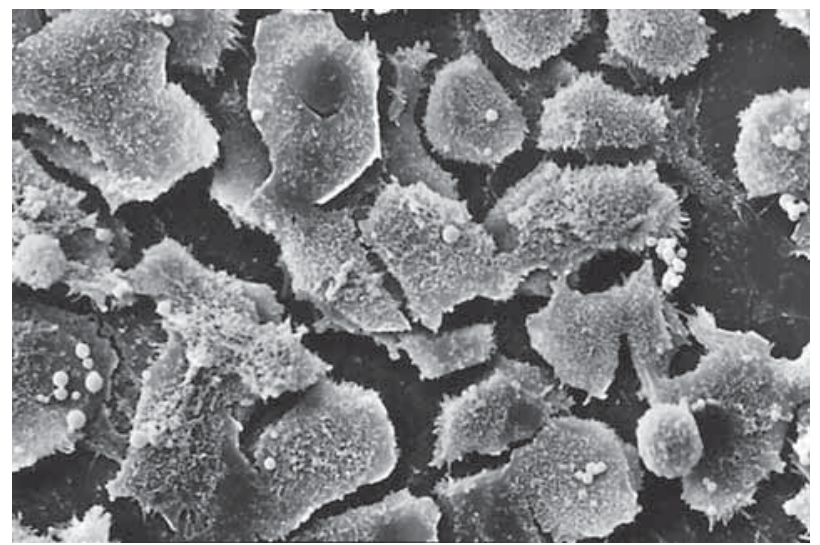

B

Figure 2- Panel of SEM micrographs representative of cell morphology. A - Group 3 (40 s); B - Group 4 (60 s). Presence of spindle-shaped cells organized in dense nodules. (Original magnification: $\times 1,000$ )

remained adhered to the glass substrate. These cells were small-sized, round-shaped and presented few or no cytoplasmic processes originating from their membrane (Figure 3A). In G1 (dark-curing), extensive cell-free areas with a number of globular structures suggestive of composite resin fragments were also observed (Figure 3B).

\section{DISCUSSION}

Several in vitro studies have used different cell types with odontoblast phenotype to evaluate potential cytotoxic effects of dental materials and/ or their individual components ${ }^{1,6,27}$. In the present study, immortalized odontoblast-like MDPC-23 cells were used to evaluate the cytotoxic effect of an experimental resin composite because odontoblasts are organized in a monolayer that underlies the pulp chamber, being therefore the first cells to be damaged by potentially cytotoxic compounds released from dental materials capable to diffuse through dentin into the pulp space.

In this study, the direct contact of dark-cured composite resin specimens with immortalized odontoblast-like MDPC-23 cells caused an intense toxic effect, as demonstrated by an $86.2 \%$ reduction in cell metabolism. On the other hand, the

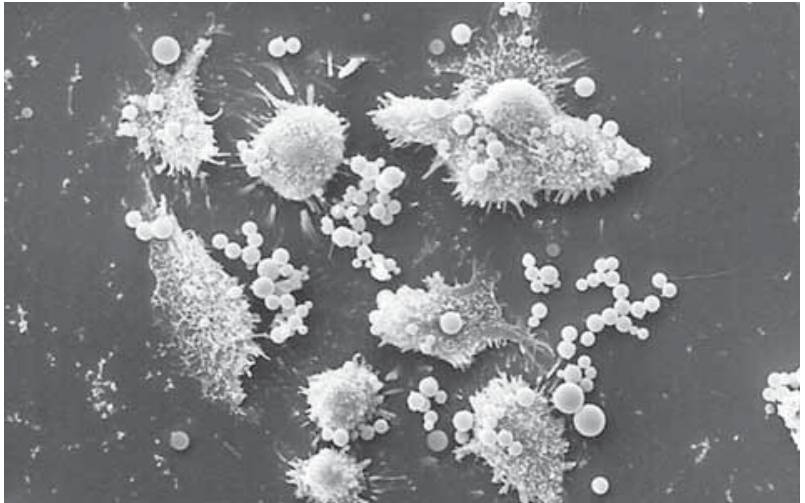

A

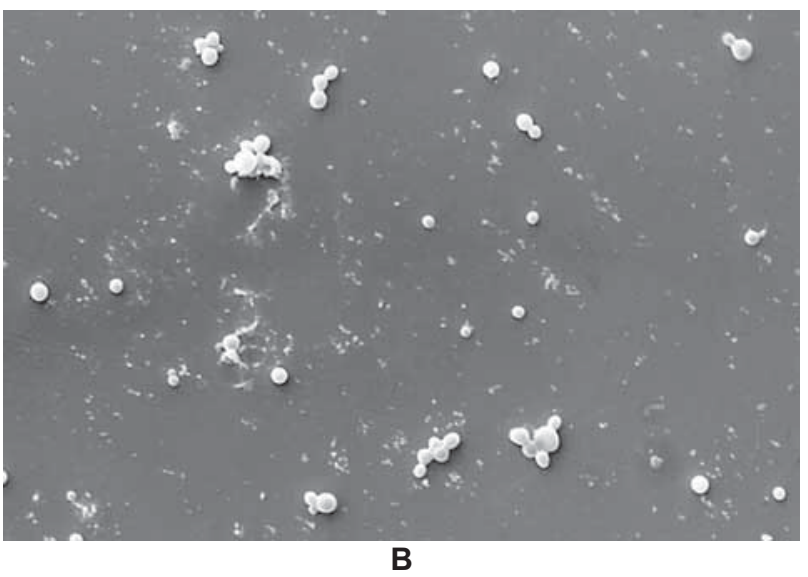

Figure 3- Panel of SEM micrographs representative of cell morphology. A - Group 2 (20 s) - Presence of few small-sized and round-shaped cells with few cytoplasmic processes; B - Group 1 (dark-curing) - Presence of a small number of cells adhered to the glass substrate and structures suggestive of rests of degraded cell components. (Original magnification: $x 1,000$ )

cytotoxic effects of the composite resin decreased significantly when the material was light-activated using the manufacturer's recommended (40 s) and a shorter (20 s) light-exposure time with a reduction of $13.3 \%$ and $13.5 \%$ in cell metabolism, respectively. No statistical significance was found between these curing times. These results are not consistent with those of Costa, et al. ${ }^{6}$ (2003), who concluded that the composite resin light-cured for $20 \mathrm{~s}$ was more cytotoxic to MDPC-23 cells than the experimental material light-cured for 40 $\mathrm{s}$, with a reduction in cell metabolism by $40.1 \%$ and $24.5 \%$, respectively. These different findings may be due to the fact that Costa, et al. ${ }^{6}$ (2003) maintained the specimens immersed in PBS and DMEM with consecutive changes in each solution at 5 -min intervals. Although the same procedure was performed, in the present study, the specimens were maintained under continuous agitation during the entire experimental period. Therefore, it may be speculated that most unreacted and highly toxic residual monomers that remained on specimen surface were eliminated by the vigorous rinsing, producing low cytotoxic effects. However, this 
supposition could only be confirmed by qualitative and quantitative analyses by mass spectrometry of the experimental composite resin components released in the PBS and DMEM after rinsing.

In the present study, a significant reduction in the cytotoxic effects occurred when the composite resin was light-activated for $60 \mathrm{~s}$ (G4) and the results were similar to those of the control group (G5). Costa, et al. $^{6}$ (2003) suggested that the cytotoxicity of the dental materials is inversely proportional to the light-curing time, which is in accordance with our results when a $60 \mathrm{~s}$ exposure to the light source was used (G4). These outcomes also agree with those of Caughmann, et al. ${ }^{3}$ (1991) who evaluated the cytotoxicity of three composite resins subjected to different light-curing times (15, 30 and $45 \mathrm{~s}$ ) and correlated the results with the monomer conversion rate. The longer the lightcuring time, the higher the monomer conversion rate and consequently the lower the cytotoxicity of each tested material.

It is known that composite resin polymerization occurs by the conversion of the monomer molecules into a polymer network. When the composite resin is underpolymerized, residual monomers may be released from the material in contact with dentin moisture and reach the pulp tissue causing severe damage associated to cell death ${ }^{9}$. In the present study, the non-light-cured experimental composite resin caused extremely severe cytotoxic effects to MDPC-23 cell line, confirming that the nonconversion of monomers into polymers result in high cytotoxicity. These toxic effects were clearly observed in the SEM analysis of cell morphology. Most of the few MDPC-23 cells that remained adhered to the glass substrate were lost due to the direct effect of the material, which caused cell damage and death by either a chemical action or induction of apoptosis. These cells exhibited a small size and round shape with few or no cytoplasmic processes (Figure 3B).

Some factors, such as light intensity and lightcuring time, are essential for the polymerization of resin materials ${ }^{4,21,22,23}$. However, when light intensity is not the limiting factor, exposure time is essential to resin polymerization ${ }^{22}$. Since light intensity was maintained about $460 \mathrm{~mW} / \mathrm{cm}^{2}$ in the present study, it may be suggested that shortening the light exposure time from 40 to $20 \mathrm{~s}$ did not influence significantly on the cytotoxic effects of the tested composite resin. However, such a difference may be observed with thicker composite resin increments. In the SEM analysis, it was observed that the shorter the light-curing time, the larger the number of structures characterized as resin fragments on the glass substrate. This finding confirms that a shorter exposure to the light source results in a lower conversion of monomers into polymers within the resin material core, leading to a greater solubilization of the components in aqueous media.
The toxicity of resin materials has been attributed to their composition 7,10,28 and processes that occur during their polymerization, such as the release of toxic components ${ }^{1,14,17,19,27}$ and temperature change ${ }^{16,25,29}$. Composite resins present an organic matrix composed of resin monomers and a zirconium/ silica inorganic matrix (nearly $70 \%$ by volume). Geurtsen, et al. ${ }^{10}(1999)$ identified in most composites the co-monomer TEGDMA (triethyleneglycoldimethacrylate) as the main component released and a small amount of the monomers Bis-GMA (bisphenol-A-glycidyl-dimethacrylate) and UDMA (urethane dimethacrylate), other co-monomers and additives. These components may produce adverse effects in the organism, allergic reactions, systemic toxicity, mutagenicity ${ }^{12,14,15}$ and cytotoxicity ${ }^{10,12,14,15}$. The residual methacrylate monomers released from underpolymerized resin materials are incorporated to the lipid bilayer of the cell membrane, causing the solubilization of this structure. This phenomenon is responsible for cell death and may explain the role of resin monomers in the cytotoxicity of composite resins $^{8}$.

The external application of heat on the dental tissues may cause pulp damage of different severities, depending on the intensity and duration of the temperature rise ${ }^{30}$. Increase of the temperature on tooth surface or even on the pulp tissue may occur during some operative procedures such as cavity preparation with rotary instruments ${ }^{20}$, laser irradiation ${ }^{5}$ or photoactivation of resin materials ${ }^{16,25,29}$. Kanshanavasita, et al. ${ }^{13}$ (1995) have shown that resin-modified glass ionomer cements and composite resins exhibited a rapid rise in temperature during light-exposure and reached a peak value within a very short time. After that, the temperature decreased immediately on removal of the light source to that of the room temperature. The authors also reported that the longer irradiation times did not produce significantly greater temperature rise, but they prolonged the period before the temperature started to decline. In the present study, the increase of temperature on the composite resin did not influence on the cytotoxicity because, according to the employed methodology, the time elapsed between lightactivation of the specimens and their direct contact with the MDPC-23 cells (15 min on average) was sufficient to allow temperature decrease.

A previous in vitro study investigating methods for evaluation of the cytotoxic effects of dental materials to cell cultures has shown that the direct cell/material contact simulates in an effective manner the in vivo condition ${ }^{2}$. However, results of laboratorial experiments cannot be directly extrapolated to clinical conditions. Therefore, before dental materials can be recommended for clinical applications, in vitro and in vivo studies should be carried out to offer clinicians and patients safety and efficacy data based on the balance among the materials' physical, mechanical, 
chemical and biological properties on the different dental tissues. The results obtained in the present in vitro investigation suggest that any factor that limits or undermines the polymerization of resin materials, such as low light intensity, short lightcuring time, longer distance between material surface and light source, may contribute to increase significantly their cytotoxic effects to the pulp cells. Therefore, it is mandatory that the manufacturers' instructions of use are strictly followed regarding the adequate photoactivation of resin materials, which is inversely related to cytotoxicity.

\section{CONCLUSIONS}

Regardless of the light-activation time used in the present investigation, the experimental composite resin presented mild to no toxic effects to the odontoblast-like MDPC-23 cells. However, intense cytotoxic effects occurred when the resinbased material was not light-cured.

\section{ACKNOWLEDGEMENTS}

This study was partially supported by grants from the Fundação de Amparo à Pesquisa do Estado de São Paulo - FAPESP (Grant 08/08424-6) and Conselho Nacional de Desenvolvimento Científico e Tecnológico - CNPq (Grant 301029/2007-5). The authors are also indebted to Prof. Dr. Elliot W. Kitajima, head of NAP/MEPA-ESALQ/USP, for use of the electron microscopy lab facilities.

\section{REFERENCES}

1- Aranha AM, Giro EM, Souza PP, Hebling J, Souza Costa CA. Effect of curing regime on the cytotoxicity of resin-modified glass ionomer lining cements applied to an odontoblast-cell line. Dent Mater. 2006;22(9):864-9.

2- Cao T, Saw TY, Heng BC, Liu H, Yap AU, Ng ML. Comparison of different test models for assessment of cytotoxicity of composite resins. J Appl Toxicol. 2005;25(2):101-8.

3- Caughman WF, Caughman GB, Shiflett RA, Rueggeberg F, Schuster GS. Correlation of cytotoxicity, filler loading and curing time of dental composites. Biomaterials. 1991;12(8):737-40. 4- Caughman WF, Rueggeberg FA, Curtis JW Jr. Clinical guidelines for photocuring restorative resins. J Am Dent Assoc. 1995;126(9):1280-6.

5- Cavalcanti BN, Lage-Marques JL, Rode SM. Pulpal temperature increases with ER:YAG laser and high-speed handpieces. J Prosthet Dent. 2003;90(5):447-51.

6- Costa CA, Oliveira MF, Giro EM, Hebling J. Biocompatibility of resin-based materials as pulp-capping agents. Int Endod J. 2003;36(12):831-9.

7- Ferracane JL, Condon JR. Rate of elution of leachable components from composite. Dent. Mater. 1990;6(4):282-7.

8- Fujisawa S, Kadoma Y, Komoda, Y. $1 \mathrm{H}$ and $13 \mathrm{C}$ NMR studies of the interaction of eugenol, phenol, and triethyleneglycol dimethacrylate with phospholipid liposomes as a model system for odontoblast membranes. J Dent Res. 1988;67(11):1438-41.
9- Gerzina TM, Hume WR. Diffusion of monomers from bonding resin-resin composite combinations through dentine in vitro. J Dent. $1996 ; 24(1-2): 125-8$.

10- Geurtsen W, Spahl W, Müller K, Leyhausen G. Aqueous extracts from dentin adhesives contain cytotoxic chemicals. J Biomed Mater Res. 1999;48(6):772-7.

11- Hanks CT, Strawn SE, Wataha JC, Craig RG. Cytotoxic effects of resin components on cultured mammalian fibroblasts. J Dent Res. $1991 ; 70(11): 1450-55$.

12- Hensten-Pettersen A. Skin and mucosal reactions associated with dental materials. Eur J Oral Sci. 1998;106(2 Pt2):707-12.

13- Kanchanavasita W, Pearson GJ, Anstice HM. Temperature rise in ion-leachable cements during setting reaction. Biomaterials. $1995 ; 6(16): 1261-5$.

14- Kleinsasser $\mathrm{NH}$, Schmid $\mathrm{K}$, Sassen AW, Harréus UA, Staudenmaier R, Folwaczny $M$, et al. Cytotoxic and genotoxic effects of resin monomers in human salivary gland tissue and lymphocytes as assessed by the single cell microgel electrophoresis (Comet) assay. Biomaterials. 2006;27(9):1762-70.

15- Lee DH, Lim BS, Lee YK, Ahn SJ, Yang HC. Involvement of oxidative stress in mutagenicity and apoptosis caused by dental resin monomers in cell cultures. Dent Mater. 2006;22(12):108692.

16- Lloyd $\mathrm{CH}$, Joshi A, McGlynn E. Temperature rises produced by light sources and composites during curing. Dent Mater. 1986;2(4):170-4.

17- Moharamzadeh K, Van Noort R, Brook IM, Scutt AM. Cytotoxicity of resin monomers on human gingival fibroblast and HaCaT keratinocytes. Dent Mater. 2007;23(1):40-4.

18- Mosmann T. Rapid colorimetric assay for cellular growth and survival: application to proliferation and cytotoxicity assays. J Immunol Methods. 1983;65(1-2):55-63.

19- Nalçaci A, Oztan MD, Yilmaz S. Cytotoxicity of composite resins polymerized with different curing methods. Int Endod J. 2004;37(2):151-6.

20- Ottl P, Lauer HC. Temperature response in the pulpal chamber during ultrahigh-speed tooth preparation with diamonds burs with different grit. J Prosthet Dent. 1998;80(1):12-9.

21- Rueggeberg FA, Caughman WF, Curtis JW Jr. Effects of light intensity and exposure duration on cure of resin composite. Oper Dent. 1994;1(1):26-32.

22- Rueggeberg FA, Caughman WF, Curtis JW Jr, Davis HC. Factors affecting cure at depths within light-activated resin composites. Am J Dent. 1993;6(2):91-5.

23- Sakaguchi RL, Douglas WH, Peters MC. Curing light performance and polymerization of composite restorative materials. J Dent. 1992;20(3):183-8.

24- Sideridou ID, Achilias DS. Elution study of unreacted BisGMA, TEGDMA, UDMA, and Bis-EMA from light-cured dental resins and resin composites using HPLC. J Biomed Mater Res B Appl Biomater. 2005;74(1):617-26.

25- Smail SR, Patterson CJ, McLundie AC, Strang R. In vitro temperature rises during visible-light curing of a lining material and a posterior composite. J Oral Rehabil. 1988;15(4):361-6.

26- Souza Costa CA, Hebling J, Hanks CT. Effects of lightcuring time on the cytotoxicity of a restorative resin composite applied to an immortalized odontoblast-cell line. Oper. Dent. 2003;28(4):365-70.

27- Souza PP, Aranha AM, Hebling $\mathrm{H}$, Giro EM, Costa CA. In vitro cytotoxicity and in vivo biocompatibility of contemporary resinmodified glass-ionomer cements. Dent Mater. 2006;22(9):83844.

28- Spahl W, Budzikiewicz H, Geurtsen W. Determination of leachable components from four commercial dental composites by gas and liquid chromatography/mass spectrometry. J Dent. $1998 ; 26(2): 137-45$.

29- Uhl A, Völpel A, Sigusch BW. Influence of heat from light curing units and dental composite polymerization on cells in vitro. J Dent. 2006;34(4):298-306.

30- Zach L, Cohen G. Pulp response to externally applied heat. Oral Surg Oral Med Oral Pathol. 1965;19:515-30. 